\title{
Karakteristik Beton Mutu 16,9 MPa Mengunakan 1\% Kawat Bendrat dengan Variasi Panjang
}

\author{
Tri Mulyono \\ Program Studi Transportasi, Fakultas Teknik, Universitas Negeri Jakarta, Indonesia \\ E-mail: trimulyono@unj.ac.id
}

Received 29 October 2021; Reviewed 15 November 2021; Accepted 08 December 2021 Journal Homepage: http://jurnal.borneo.ac.id/index.php/borneoengineering

\begin{abstract}
The research aimed to determine the characteristics of the $16.9 \mathrm{MPa}$, using steel fibers (bendrat wire) with lenght variations in the concrete mixture $1 \%$ by volume-weight of the concrete. This research is an explanatory research with research questions are: how significant is the difference, and what are the characteristics. The total population of each treatment is 12 specimens with a sample of 5 specimens for compressive strength and 4 specimens for split tensile strength for each given treatment which is a random sample, specifically: A (reference concrete); $B, C, D$, and $E$ for concrete with length variation an expressed as L/D fiber ratio of 50; 62.5; 75 and 87.5. The concrete material meets the standard. At the level of significance 0,05 indicates that the test data are normal distribution and uniform and the characteristics of concrete between reference concrete and concrete fiber different variance values. The unit weight between the reference concrete and the fiber concrete is slightly identical. The slump value decreases with increasing $L / D$ fiber ratio. The concrete characteristics increase up to an L/D fiber ratio of 75 . It generates a compressive strength of $19.47 \%$ of the design and $16.60 \%$ of the reference concrete $(17,316 \mathrm{MPa})$. The split tensile strength is 2,753 $\mathrm{MPa}(22.29 \%$ higher than the design 2,251 $\mathrm{MPa})$ and $18.83 \%$ of the reference concrete $(2,317 \mathrm{MPa})$. The flexural strength was $3.638 \mathrm{MPa}(18.01 \%$ of the $3.083 \mathrm{MPa}$ design) and $1.97 \%$ of the reference concrete $(3.144 \mathrm{MPa})$.
\end{abstract}

Keywords: Compressive Strength, Split Tensile Strength, Flexural Strength, Steel Fiber, L/D Ratio

\begin{abstract}
Abstrak
Penelitian ini bertujuan untuk mengetahui karakteristik beton mutu 16,9 MPa, menggunakan serat baja (kawat bendrat) dengan variasi panjang pada campuran beton dengan $1 \%$ berat volume. Penelitian ini merupakan penelitian penjelasan denganpertanyaan penelitiannya adalah seberapa signifikan perbedaannya, dan bagaimana karakteristiknya. Jumlah populasi masing-masing perlakuan adalah 12 benda uji dengan sampel adalah 5 benda uji kuat tekan dan 4 benda uji kuat tarik belah untuk setiap perlakuan yang diberikan yang merupakan sampel acak, yaitu: A (beton referensi); $B, C, D$, dan $E$ untuk beton dengan variasi panjang dinyatakan dengan rasio serat $L / D$ 50; 62.5; 75 dan 87,5. Hasil pengujian material beton memenuhi standar. Taraf signifikansi 0,05 menunjukkan bahwa data uji berdistribusi normal dan seragam serta karakteristik beton antara beton referensi dan beton yang menggunakan variasi L/D memiliki nilai varians yang berbeda. Berat isi beton antara beton referensi dan yang menggunakan variasi rasio $L / D$ sedikit berbeda. Nilai slump menurun dengan meningkatnya rasio L/D. Karakteristik beton meningkat sampai rasio L/D 75. Menghasilkan kuat tekan 19,47\% dari desain dan 16,60\% dari beton referensi 1 (17,316 $\mathrm{MPa})$. Kuat tarik belah didapatkan $2.753 \mathrm{MPa}(22,29 \%$ lebih tinggi dari desain $2.251 \mathrm{MPa})$ dan 18,83\% dari beton referensi $(2.317 \mathrm{MPa})$. Kuat lentur sebesar 3,638 MPa (18,01\% dari desain 3,083 MPa) dan 1,97\% dari beton referensi $(3,144 \mathrm{MPa})$.
\end{abstract}

Kata kunci: Kuat Tekan, Kuat Tarik Belah, Kuat Lentur, Serat Baja, Rasio L/D 


\section{Pendahuluan}

Dokumen mutu beton akan tergantung dari bahan/material pembentuk ataupun pada proses pembuatannya. Kualitas bahan dan proses pelaksanaannya harus dikendalikan agar dicapai hasil yang optimal terhadap proporsinya. Standar Nasional Indonesia memberikan proporsi campuran pekerjaan beton untuk konstruksi bangunan gedung dan perumahan dari mutu 7,4 -31,2 Mpa (Peraturan Menteri Pekerjaan Umum Dan Perumahan Rakyat Republik Indonesia Nomor 28/PRT/M/2016 Tentang Pedoman Analisis Harga Satuan Pekerjaan Bidang Pekerjaan Umum, 2016). Beton lemah terhadap kuat tarik, dengan memberi tulangan pada beton menggunakan serat baja yang disebarkan secara merata (uniform) kedalam adukan beton, harapannya beton dapat memenuhi mutu yang diharapkan. Berbagai jenis bahan fiber yang dapat dipakai untuk memperbaiki sifat beton adalah baja (steel), plastik (polypropylene), polymers, asbes dan carbon (Mulyono, 2003, 2015). Beton serat digunakan pada konstruksi yang harus mempunyai permukaan luas di mana temperatur, oksidasi, dan penguapan mempunyai pengaruh besar terhadap besarnya susut muai, seperti landasan pacu di bandar udara, pelat atap, jalan, dan lain-lain (Mulyono, 2021).

Berbagai bahan rekayasa (termasuk keramik, plastik, semen, dan produk gipsum) menggabungkan serat untuk meningkatkan sifat komposit (ACI 544.5R, 2010). Sifat-sifat yang ditingkatkan termasuk kekuatan tarik, kekuatan tekan, modulus elastis, ketahanan retak, kontrol retak, daya tahan, umur lelah, ketahanan terhadap benturan dan abrasi, susut, ekspansi, karakteristik termal, dan tahan api. Beberapa tipikal serat yaitu baja, kaca, organik dan mineral alami, polypropylene, sintetis lainnya. Parameter praktis yang mendeskripsikan serat adalah rasio aspeknya (L/D), yang didefinisikan sebagai panjang serat dibagi dengan diameter serat. Rasio tipikal berkisar dari sekitar 30 hingga 150 untuk panjang 6 hingga 75mm (Wafa, 1990). Rasio aspek (ACI 544.5R, 2010) khususnya berkisar dari sekitar 20 hingga 100, sedangkan dimensi panjang berkisar dari 6,4 hingga $76 \mathrm{~mm}$.

Serat baja seperti kawat bendrat akan meningkatkan karakteristik fisik melalui aksi komposit pada beton struktural, beberapa pustaka yang relevan dan terkini yang berhubungan dengan penelitian sebagai "state of the arts", untuk pengunaan serat kawat bendrat pada campuran beton terhadap kuat tekan dan kuat tarik beton menunjukan kandungan serat 2\% memberikan kuat tekan 25,59 MPa dan kuat tarik belah 2,38 MPa lebih besar dibandingkan kuat tekan rencana 20,92 MPa (Juwarnoko, 2019). Saat serat yang digunakan ditekuk pada kedua ujungnya dibandingkan dengan serat yang lurus, kuat tekan tidak berpengaruh (Kawulusan et al., 2019; Malino et al., 2019). Hasil penelitian lainnya dengan penambahan serat kawat pada beton, kuat tekan meningkat dibandingkan beton normal. Kuat tekan yang diperoleh 16,18 MPa dengan berat serat kawat 2,0\% dan panjang $\pm 50 \mathrm{~mm}$ menunjukan peningkatan kuat tekan beton 11,35\% (Sugiarto, 2017). Penggabungan serat kawat bendrat $0,5-1,5 \%$ dan panjang $60 \mathrm{~mm}$ dengan serat kaca $10 \%$ dalam campuran beton menghasilkan proporsi optimum serat kawat bendrat $1,5 \%$ dan serat kaca $10 \%$. Kuat tekannya 16,25 MPa dan kuat tarik belah 4,64 MPa meningkat 31,81\% dari kuat tekan tanpa serat (Uluhiyah, 2018). Pengaruh campuran beton normal dengan penambahan kawat bendrat terhadap beton normal dengan hasil kuat tekan pada umur beton 14 dan 28 hari secara berurutan kekuatan tekan 34,31\% dan 20,47\% (Kurniawan, 2021). Kuat tekan dengan serat kawat bendrat dapat mencapai 42,14 MPa (Prayitno et al., 2016) yang optimalnya dengan menggunakan panjang $6 \mathrm{~cm}$ pada proporsi $0,75 \%$ berat volume (Foermansah, 2013; Nugraha, 2018). Penambahan serat dalam campuran beton dapat meningkatkan kuat geser beton (Hafiz S.G et al., 2015). Metode perawatan beton juga akan menghasilkan kuat tekan yang berbeda, dengan perawatan dengan perendaman akan lebih tinggi dibandingkan dengan dirawat kering pada beton serat (Junus, 2017).

Volume serat dalam campuran beton akan memberikan efek pada kekuatan, meningkat secara linear, kekuatan tarik dan kekuatan komposit. Penggunaan persentase serat yang lebih tinggi 
cenderung menyebabkan pemisahan dan kekerasan beton dan mortar menurun. Dalam kisaran tipikal fraksi volume yang digunakan untuk beton yang dicor setempat (cast-in-place), Steel fiberreinforced concrete (SFRC) sebesar 0,25 hingga 1,5 persen volume, penambahan serat baja dapat mengurangi nilai slump yang diukur dari komposit dibandingkan dengan campuran non-serat dalam kisaran 25 hingga $102 \mathrm{~mm}$ (ACI 544.5R, 2010).

Kuat lentur beton yang diperkuat dengan bahan serat penguat seperti serat baja, aramit atau serat karbon, umur 28 hari, yang didapat dari hasil pengujian balok dengan pembebanan titik ketiga (third-point) sesuai ASTM C78/C78M-21"Standard Test Method for Flexural Strength of Concrete (Using Simple Beam with Third-Point Loading)" atau menurut SNI 4431-2011 "Cara Uji Lentur Beton Dengan Dua Titik Pembebanan". Tipikal kuat lentur menurut Pd T-14-2003, (2003) sekitar 3-5 MPa (30-50 kg/ $\left.\mathrm{cm}^{2}\right)$. Metode pembebanan titik ketiga digunakan dalam uji lentur beton yang menggunakan blok bantalan dan memastikan bahwa gaya yang diterapkan pada balok akan tegak lurus terhadap permukaan benda uji dan diterapkan tanpa eksentrisitas.

Hubungan antara kuat tekan karakteristik dengan kuat tarik-lentur beton dapat didekati dengan Pers. 1 dalam MPa dan Pers. 2 dalam $\mathrm{kg} / \mathrm{cm}^{2}$. Kuat lentur dapat juga ditentukan dari hasil uji kuat tarik belah beton $\left(f_{c S}\right)$ yang dilakukan menurut SNI 2491:2014 dengan Pers. 3 dalam MPa dan Pers. 4 dalam $\mathrm{kg} / \mathrm{cm}^{2}$ sesuai Pd T-14-2003, (2003), sebagai berikut:

$$
\begin{aligned}
& f_{c f}=K\left(f_{c}^{\prime}\right)^{0,50} \\
& f_{c f}=3,13 K\left(f_{c}^{\prime}\right)^{0,50} \\
& f_{c f}=1,37 f_{c s} \\
& f_{c f}=13,44 f_{c s}
\end{aligned}
$$

dengan,

$f_{c f}=$ kuat lentur beton umur 28 hari $\left(\mathrm{MPa}\right.$ atau $\left.\mathrm{kg} / \mathrm{cm}^{2}\right)$,

$f_{c}^{\prime}=$ Kuat tekan beton umur 28 hari $\left(\mathrm{MPa}\right.$ atau $\left.\mathrm{kg} / \mathrm{cm}^{2}\right)$,

$f_{c s}=$ Kuat tarik belah beton umur 28 hari (MPa atau $\left.\mathrm{kg} / \mathrm{cm}^{2}\right)$,

$K \quad=$ konstanta dengan nilai $K=0,70$ untuk agregat tidak dipecah dan $K=0,75$ untuk agregat pecah.

Merujuk pada uraian di atas dan "state of the arts", memunculkan pertanyaan: (1) Seberapa besar signifikasi perbedaan beton mutu 16,9 MPa menggunakan serat kawat baja (bendrat) proporsi $1 \%$ dalam campuran dengan variasi panjang (rasio L/D)?, dan (2) Bagaimana karakteristik kuat tekan, kuat tarik belah beton mutu 16,9 MPa menggunakan serat kawat baja (bendrat) dengan proporsi $1 \%$ dalam campuran dengan variasi panjang (rasio L/D)?

\section{Metode Penelitian}

Penelitian ini merupakan penelitian penjelasan dengan metode yang digunakan studi eksprimen di Laboratorium Uji Bahan Universitas Negeri Jakarta selama periode Juni - Oktober 2021. Beberapa metode pemeriksaan bahan penyusun beton dan beton yang dapat digunakan mengikuti standar nasional indonesia (SNI). Metode, spesifikasi dan Tata Cara yang digunakan dalam penelitian ini yaitu Bagian 1: Batuan, Sediman, Agregat dan Bagian 3:Beton, Semen, Perkerasan Beton Semen. Metode yang digunakan untuk pemeriksaan bahan agregat dapat dilihat di Tabel 1. Proporsi yang digunakan dalam pencampuran bahan sesuai Tabel 2. Populasi dalam penelitian adalah sejumlah data yang didapatkan dari contoh uji (specimen) berupa benda uji silinder beton untuk setiap perlakuan. Sample berupa sejumlah data yang diambil secara acak dalam populasi. Banyaknya 
populasi untuk setiap perlakuan 12 specimen dan sampel sebanyak 5 specimen untuk uji tekan dan 4 specimen untuk uji tarik belah. Nilai kuat lentur, $f_{c f}$ di intreprestasikan dari hasil uji kuat tekan, $f_{c}^{\prime}$ dan tarik belah, $f_{c s}$ menggunakan Pers. 1 dan Pers. 3. Sebelum dideskripsikan lebih lanjut, data di uji pesryaratan analisis dan hipotesis, sesuai pertanyaan pertama penelitian. Selanjutnya dideskripsikan untuk mengetahui bagaimana karakterisitik beton mutu 16,9 MPa sesuai Butir B.06 Permen PUPR No. 28/PRT/M/2016.

\section{Hasil Penelitian dan Diskusi}

\subsection{Hasil Pengujian Bahan Penyusun Beton dan Beton}

\subsubsection{Pengujian Bahan Penyusun Beton}

Bahan semen, air dan tambah kimia menggunakan Plastocrete 1003 tidak dilakukan pengujian dalam penelitian ini. Bahan beton yang diuji hanya untuk agregat. Pemeriksaan agregat menggunakan SNI dengan hasil pemeriksaan bahan diuraikan sebelumnya. Data-data yang digunakan untuk perancangan adalah data hasil uji bahan-bahan penyusun dengan kondisi jenuh permukaan kering (JPK). Material untuk agregat halus bersumber dari toko material yang berada di sekitar Rawamangun. sumber asal agregat umumnya dari daerah Bogor. Hasil uji untuk agregat seperti Tabel 1. Gradasi agregat halus memenuhi zona (daerah) untuk pasir sedang dan untuk agregat kasar (batu pecah) memenuhi butir maksimum $40 \mathrm{~mm}$.

Tabel 1. Hasil Pengujian Agregat Halus dan Kasar

\begin{tabular}{|c|c|c|c|}
\hline \multirow{2}{*}{ Deskripsi Pengujian } & \multirow{2}{*}{ Metode } & \multicolumn{2}{|c|}{ Data Pengujian } \\
\hline & & Agregat Halus & Agregat Kasar \\
\hline Kadar Air Jenuh Permukaan & & & \\
\hline Kering (JPK) & (ASTM C /0-13; SNI & $2,995 \%$ & $1,025 \%$ \\
\hline Kering Tungku & 8319:2016) & $3,465 \%$ & $1,066 \%$ \\
\hline Berat Isi Gembur & (ASTM C29 / C29M - 17a; & $1627 \mathrm{~kg} / \mathrm{m}^{3}$ & $1539 \mathrm{~kg} / \mathrm{m}^{3}$ \\
\hline Padat & SNI 03-4804-1998) & $1662 \mathrm{~kg} / \mathrm{m}^{3}$ & $1556 \mathrm{~kg} / \mathrm{m}^{3}$ \\
\hline Berat Jenis kering oven & (ASTM C128 - 15; SNI & 2,698 & 2,489 \\
\hline JPK & 1970:2016) & 2,822 & 2,563 \\
\hline Semu & & 3,080 & 2,563 \\
\hline Penyerapan & & $4,589 \%$ & $1,158 \%$ \\
\hline $\begin{array}{l}\text { Kandungan lumpur } \\
\text { (Syarat SNI <5\%) }\end{array}$ & $\begin{array}{c}\text { (ASTM C142 / C142M - } \\
\text { 17; SNI 03-4428-1997) }\end{array}$ & $3,915 \%$ & - \\
\hline $\begin{array}{l}\text { Kandungan lumpurdan } \\
\text { partikel halus }\end{array}$ & $\begin{array}{c}\text { (ASTM C142 / C142M - } \\
\text { 17; SNI 03-4428-1997) }\end{array}$ & $3,770 \%$ & - \\
\hline Kandungan organik & $\begin{array}{c}\text { (ASTM C40 / C40M - 16; } \\
\text { SNI 2816:2014) }\end{array}$ & Organic Plate No. 3 & - \\
\hline Analisa Saringan & (SNI ASTM C136:2012) & Pasir sedang & Maks. $40 \mathrm{~mm}$ \\
\hline Modulus Halus Butir & & 2,69 & 7,28 \\
\hline $\begin{array}{l}\text { Agregat Gabungan } 40 \% \text { pasir } \\
\text { dan } 60 \% \text { bt. Pecah untuk } \\
\text { beton serat }\end{array}$ & $\begin{array}{c}\text { (ACI 544.5R, 2010; ACI } \\
\text { Comittee 544, 2002) }\end{array}$ & $\begin{array}{r}\text { Memenuhi syarat un } \\
\mathrm{mm}\end{array}$ & $\begin{array}{l}\text { butir maksimum } 40 \\
\text { nm) }\end{array}$ \\
\hline
\end{tabular}

Menggunakan proporsi campuran percobaan untuk agregat gabungan, $40 \%$ agregat halus dan $60 \%$ agregat kasar dan diplotkan pada batas gradasiuntuk gradasi agregat untuk beton dengan serat baja (ACI 544.5R, 2010; ACI Comittee 544, 2002). Hasil penggabungan untuk kedua jenis dan ukuran agregat seperti ditampilkan pada Gambar 1, memenuhi syarat gradasi sesuai ACI 544.R (2002;2010). 


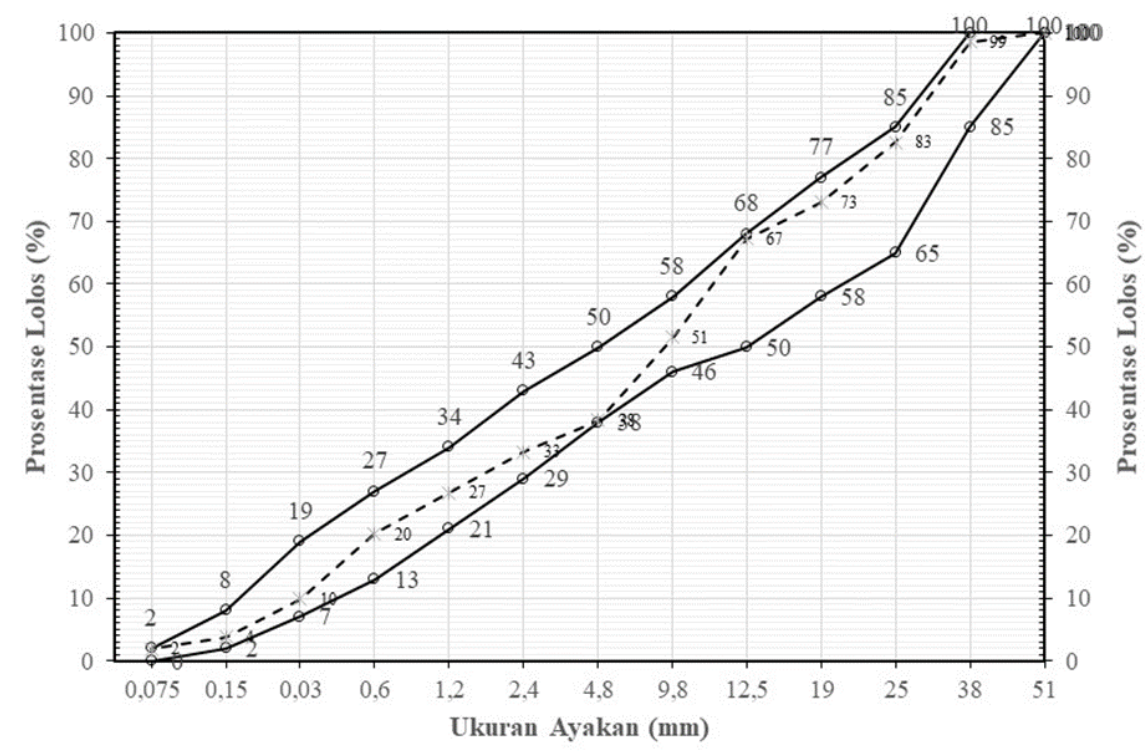

Gambar 1 Agregat gabungan 40\% agregat halus (pasir) dan 60\% agregat kasar (batu pecah) memenuhi syarat untuk beton serat sesuai ACI Comittee 544, 2010

\subsubsection{Rancangan Campuran}

Rancangan campuran percobaan dengan menggunakan proporsi yang tertuang dalam Butir B.06 Permen PUPR No. 28/PRT/M/2016, dengan rencana kuat tekan 16,9 MPa, untuk membuat $1 \mathrm{~m}^{3}$ beton mutu $\mathrm{f}^{\prime} \mathrm{c}=16,9 \mathrm{MPa}(\mathrm{K} 200)$, slump $(12 \pm 2) \mathrm{cm}$, w/c $=0,61$, proporsi bahan campurannya di Tabel 2. Variasi rasio L/D untuk 5 perlakuan, A-Beton tanpa serat atau referensi; B-Beton serat L/D 50,0; C-Beton serat L/D 62,5; D-Beton serat L/D 75; dan E-Beton serat L/D 87,5. Serat yang digunakan adalah serat baja dari potongan kawat bendrat dengan diameter $0,8 \mathrm{~mm}$ sepanjang $\pm 4,5$, 6 dan $7 \mathrm{~cm}$.

Tabel 2. Proporsi Rancangan Campuran Beton Mutu 16,9 MPa

\begin{tabular}{lc}
\hline \multicolumn{1}{c}{ Bahan Penyusun Beton } & Berat $\left(\mathrm{kg} / \mathrm{m}^{3}\right)$ \\
\hline Semen & 352,00 \\
Pasir Beton & 731,00 \\
Batu Pecah & 1031,00 \\
Air & 215,00 \\
Superplastisizer (SIKA Plastocrete 1003), 2\% & 4,30 \\
Serat Baja (Bendrat) 1\% dari berat Volume & 23,33 \\
\hline Jumlah & 2356,63 \\
\hline
\end{tabular}

\subsubsection{Pencampuran dan Data Hasil Pengujian Beton Keras}

Pengadukan berdasarkan komposisi bahan pada Tabel 2. Benda uji dibuat dengan menggunakan silinder beton. Benda uji sebelum dicetak dilakukan pengujian uji slum seperti dalam Tabel 3 .

Tabel 3. Hasil Rata-Rata Pengujian Slump dan Berat Isi

\begin{tabular}{|c|c|c|}
\hline Perlakukan (Rasio L/D) & Hasil Uji Slum (mm) & Berat Isi $\left(\mathrm{kg} / \mathrm{m}^{3}\right)$ \\
\hline A-Beton tanpa serat atau referensi & 95 & 2.210 \\
\hline B-Beton serat L/D 50,0 & 65 & 2.155 \\
\hline C-Beton serat L/D 62,5 & 75 & 2.202 \\
\hline D-Beton serat L/D 75 & 60 & 2.160 \\
\hline E-Beton serat L/D 87,5. & 70 & 2.226 \\
\hline
\end{tabular}


Benda uji ditimbang untuk mengetahui berat isinya setelah perawatan dengan perendaman selama 28 hari, sebelum dilakukan pengujian beton keras. Berat isi rata-rata berat isi benda uji, hasilnya seperti di Tabel 3. Hasil pengujian kuat tekan $\left(f_{c}^{\prime}\right)$ dan kekuatan tarik belah, $f_{c s}$ dengan pembebanan benda uji $(\mathrm{kN})$ untuk beton serat $1 \%$ berat volume dengan variasi panjang (L/D) memberikan kuat tekan dan kuat tarik belah rata-rata sesuai Tabel 4 dan Gambar 2. Nilai kuat tekan rencana diambil berdasarkan nilai yang tercantum di Butir B.06 Permen PUPR No. 28/PRT/M/2016, sesuai proporsi campuran di Tabel 2 . Hasil uji kuat tarik belah, $f_{c s}$, seperti yang ditunjukan pada Tabel 4 dan Gambar 3, nilai kuat tarik belah rencana dicari dengan menggunakan Pers. 3 yang disubstitusikan ke Pers. 1, didapatkan Pers. 5 dalam MPa, dengan nilai $K=0,75$ untuk batu pecah, didapatkan untuk nilai kuat beton 16,9 MPa, $f_{c s}=2,251 \mathrm{MPa}$ (Pd T-14-2003, 2003).

dengan:

$$
f_{C S}=\frac{\left[K\left(f_{c}^{\prime}\right)^{0,50}\right]}{1,37}=0,547\left(f_{c}^{\prime}\right)^{0,50}
$$

$f_{c S}=$ kuat tarik belah beton umur 28 hari $(\mathrm{MPa})$,

$f_{C}^{\prime}=$ kuat tekan umur 28 hari $(\mathrm{MPa})$.

Tabel 4. Rata-rata Kuat Tekan Dan Tarik Belah Silinder Beton, MPa

\begin{tabular}{lcc}
\hline \multicolumn{1}{c}{ Perlakukan (Rasio L/D) } & Kuat Tekan & Kuat Tarik Belah \\
\hline A-Beton tanpa serat atau referensi & 17,316 & 2,317 \\
B-Beton serat L/D 50,0 (Panjang, L+ 40 mm; D =0,8 mm) & 18,504 & 2,387 \\
C-Beton serat L/D 62,5 (Panjang, L \pm 50 mm; D =0,8 mm) & 19,976 & 2,458 \\
D-Beton serat L/D 75 (Panjang, L \pm 60 mm; D =0,8 mm) & 20,485 & 2,582 \\
E-Beton serat L/D 87,5 (Panjang, L+ 70 mm; D =0,8 mm) & 18,844 & 2,440 \\
\hline
\end{tabular}

Kuat lentur beton serat $1 \%$ dengan variasi panjang yang dinyatakan dalam rasio L/D hasil konversi kuat tekan ke lentur dan kuat tarik belah ke lentur yang menggunakan Pers. 1 untuk konversi dari hasil uji kuat tekan, $f_{c}^{\prime}$ ke kuat lentur beton $f_{c f}$, dan Pers. 3 untuk hasil uji kuat tarik belah, $f_{c s}$ ke kuat lentur beton $f_{c f}$. Hasil konversi seperti di Tabel 5, dengan n-data 1 sampai 5 dari data kuat tekan dan 6-9 dari hasil uji tarik belah dan rata-rata kuat lentur seperti di Gambar 4.

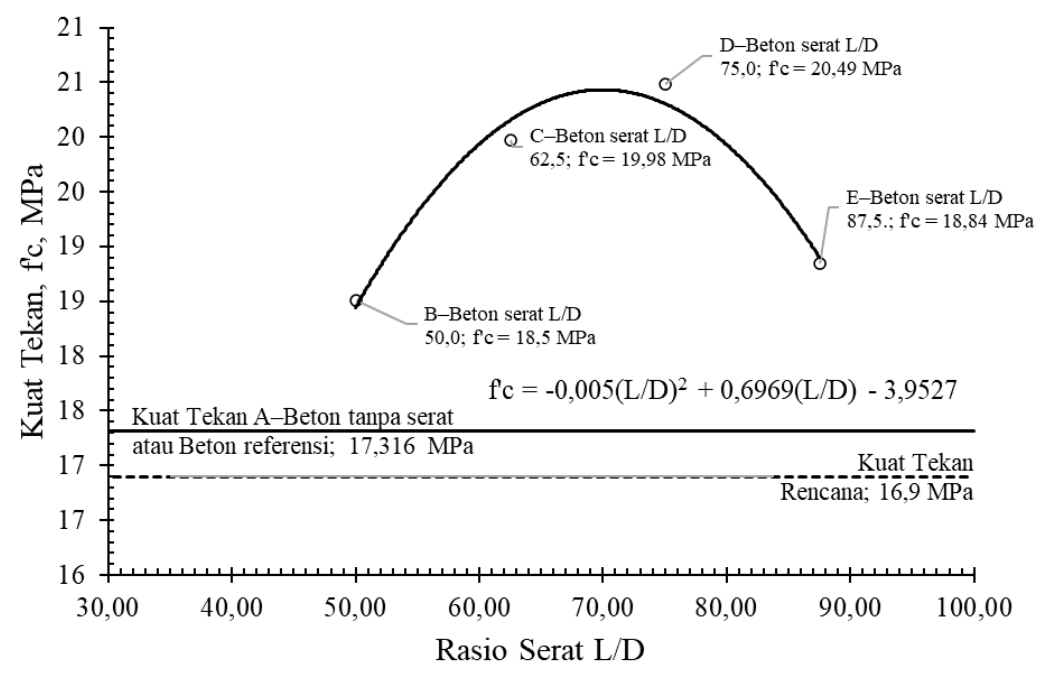

Gambar 1 Kuat tekan beton serat $1 \%$ berat volume dengan variasi rasio L/D 


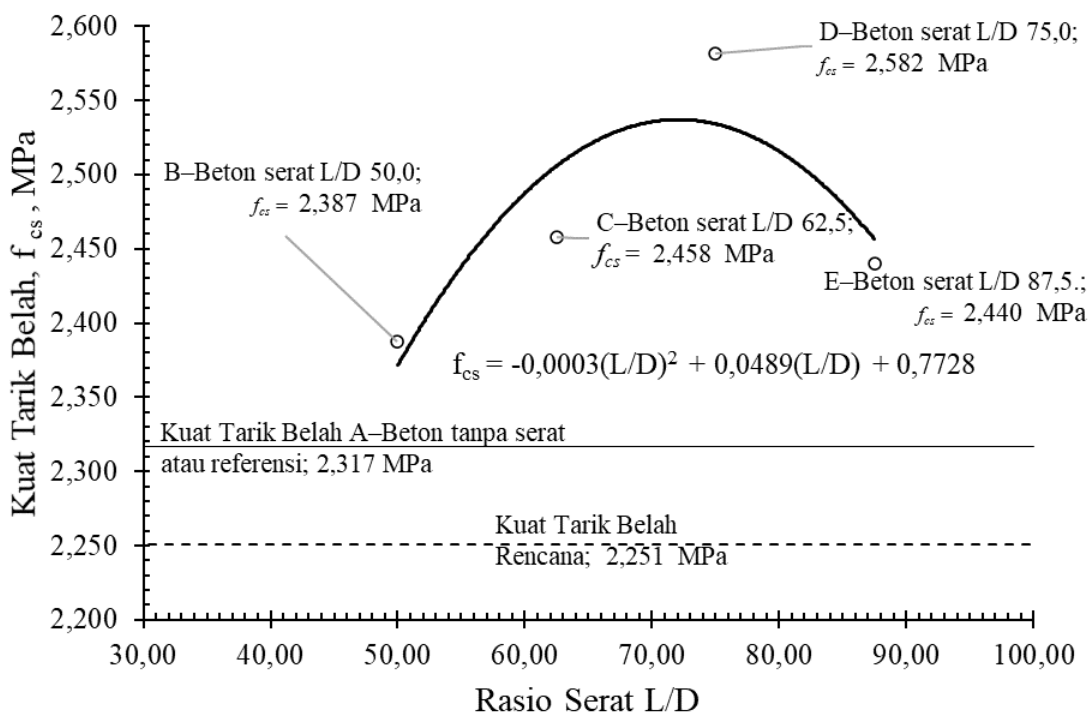

Gambar 2 Kuat tarik belah beton serat $1 \%$ berat volume dengan variasi rasio $\mathrm{L} / \mathrm{D}$

Tabel 5. Konversi Kuat Tekan dan Tarik Belah Silinder Beton ke Kuat Lentur Beton, MPa

\begin{tabular}{|c|c|c|c|c|c|}
\hline n-Data & $\begin{array}{c}\text { A-Beton } \\
\text { tanpa serat } \\
\text { atau referensi }\end{array}$ & $\begin{array}{c}\text { B-Beton serat } \\
\text { L/D 50,0 }\end{array}$ & $\begin{array}{c}\text { C-Beton serat } \\
\text { L/D 62,5 }\end{array}$ & $\begin{array}{c}\text { D-Beton } \\
\text { serat L/D } \\
\mathbf{7 5 , 0} \\
\end{array}$ & $\begin{array}{c}\text { E-Beton } \\
\text { serat L/D } \\
87,5 . \\
\end{array}$ \\
\hline 1 & 3,012 & 3,141 & 3,385 & 3,501 & 3,167 \\
\hline 2 & 3,116 & 3,192 & 3,455 & 3,613 & 3,290 \\
\hline 3 & 3,241 & 3,314 & 3,290 & 3,478 & 3,216 \\
\hline 4 & 3,167 & 3,192 & 3,478 & 3,064 & 3,038 \\
\hline 5 & 3,064 & 3,290 & 3,141 & 3,290 & 3,546 \\
\hline 6 & 3,004 & 3,295 & 2,520 & 3,682 & 3,586 \\
\hline 7 & 3,876 & 3,586 & 4,070 & 3,586 & 3,101 \\
\hline 8 & 2,520 & 2,810 & 2,907 & 3,973 & 3,876 \\
\hline 9 & 3,295 & 3,392 & 3,973 & 2,907 & 2,810 \\
\hline Mean & 3,144 & 3,246 & 3,358 & 3,455 & 3,292 \\
\hline Standar Deviasi & 0,354 & 0,210 & 0,483 & 0,325 & 0,325 \\
\hline Min & 2,520 & 2,810 & 2,520 & 2,907 & 2,810 \\
\hline Maks & 3,876 & 3,586 & 4,070 & 3,973 & 3,876 \\
\hline
\end{tabular}

\subsubsection{Hipotesis Statistik}

Merujuk dengan pertanyaan penelitian pertama, maka diperlukan analisis statistik untuk persyaratan analisis dan uji hipotesis sebelum di analisis lebih lanjut. Persyaratan analisis dilakukan dengan uji normalitas dan keseragaman dengan data yang digunakan dari Tabel 5. Hasil uji normalitas dengan metode Saphiro-Wilk dengan alat bantu MS-excel menghasilkan nilai SaphiroWilk hitung berturut-turut 0,$0073 ; 0,0045 ; 0,0022 ; 0,0000$ dan 0,0067. Nilai Tabel Saphiro-Wilk pada taraf nyata, $\alpha=0,05$ untuk 9 data sebesar 0,829 , jadi menolak $H_{0}$ atau data dinyatakan terdistribusi normal. Hasil uji varian untuk melihat homogenitas data dengan alat bantu dari VBA MS-Excel "F-Test Two-Sample for Variances" yaitu membandingkan varian beton tanpa serat dengan beton yang menggunakan serat pada variasi rasio L/D. Hasil uji memberikan nilai F-hitung berturut-turut: 2,848; 0,537; 1,187 dan 1,185. Hasil ini menunjukan semua perlakuan beton dengan serat dibandingkan dengan beton tanpa serat, memberikan nilai F-hitung lebih kecil dari F-kritis, sebesar 3,438. Hal ini berarti data semuanya seragam (homogen). 
Hipotesis statistik dinyatakan dengan $H_{0}: \mu_{0}=\mu_{1}$ dan $H_{1}: \mu_{0} \neq \mu_{1}$, dengan $\mu_{0}$ adalah karakteristik beton mutu $16,9 \mathrm{MPa}$ atau karakteristik beton referensi, dan $\mu_{1}$ yaitu karakteristik beton hasil uji dengan menggunakan serat baja $1 \%$ berat volume campuran dengan variasi rasio L/D. Hasil uji tTest dengan membandingkan rata-rata berpasangan antara beton tanpa serat dengan yang menggunakan serat menggunakan fungsi "Data Analysis" dari VBA MS-Excel untuk "t-Test: Paired Two Sample for Means" menunjukan bahwa ada perbedaan rata-rata antara beton tanpa serat dengan yang tidak menggunakan serat atau beton referensi.

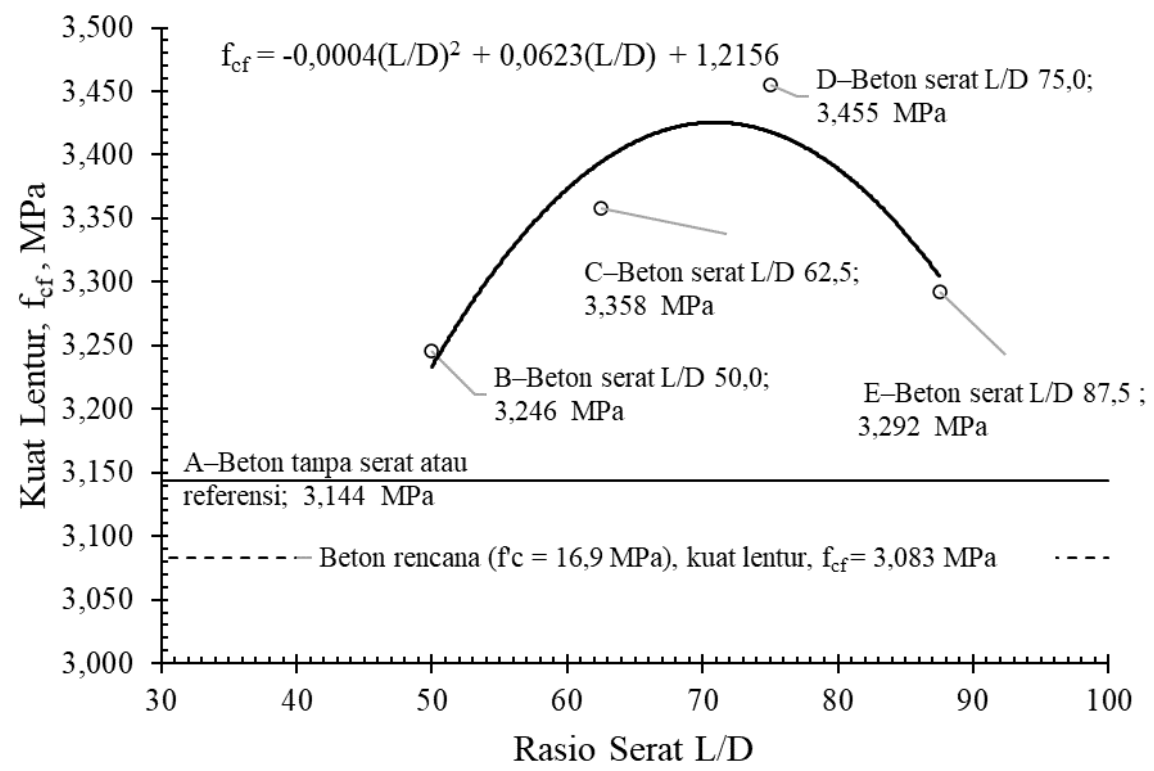

\section{Gambar 3 Hasil konversi kuat tekan dan tarik belah kuat beton serat 1\% berat volume dengan variasi rasio $\mathrm{L} / \mathrm{D}$ ke kuat lentur}

\subsubsection{Karakteristik Nilai Slump dan Berat Isi Beton Serat $1 \%$ dari Berat Volume}

Merujuk pada Tabel 3, nilai slump beton serat cenderung lebih kecil dibandingkan dengan beton referensi yang menghasilkan nilai slump $95 \mathrm{~mm}$ lebih kecil $20,83 \mathrm{~mm}$ dari rencana $120 \pm 20 \mathrm{~mm}$, atau penurunan sekitar 20-35 mm dari beton referensi. Hal ini sesuai dengan (ACI 544.5R, 2010) bahwa penambahan serat baja dapat mengurangi nilai slump yang diukur dari komposit dibandingkan dengan campuran non-serat dalam kisaran 25 hingga $102 \mathrm{~mm}$. Berat isi untuk beton dengan mutu 16,9 MPa sesuai Butir B.06 Permen PUPR No. 28/PRT/M/2016 memberikan berat isi antara 2,155-2,226 t/m $\mathrm{m}^{3}$ dari berat isi rencana atau 2,357 $\mathrm{t} / \mathrm{m}^{3}$ lebih kecil antara 5,6-8,6\%. Beton

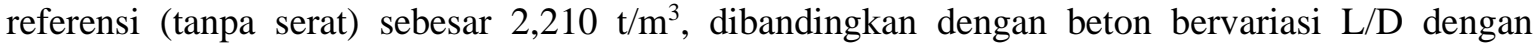
perbedaan antara 0,70-2,49\% dibandingkan dengan beton serat baja (kawat bendrat).

\subsubsection{Pengaruh Rasio L/D Pada Kuat Tekan Beton Serat 1\% dari Berat Volume}

Karakteristik kuat tekan, jika melihat Tabel 4, rata-rata kuat tekan beton tanpa serat (beton referensi) sebesar 17,316 MPa lebih besar 2,5\% dibandingkan rencana. Secara umum penambahan serat baja (kawat bendrat) $1 \%$ dalam berat volume dengan variasi L/D meningkatkan kekuatan tekan antara 9,5-21,2\% dibandingkan dengan rencana kekuatan tekan sebesar 16,9 MPa. Peningkatan kekuatan tekan terjadi pada beton dengan $1 \%$ serat dalam volume campuran dengan variasi rasio L/D yaitu pengunaan serat kawat baja (bendrat) dengan L/D 62,5 dan 75 memberikan 
nilai kuat tekan yang naik sekitar $18,2-21,2 \%$ dibandingkan kuat tekan rencana dan meningkat sebesar 15,4-18,3\% dibandingkan dengan beton referensi.

Persamaan (trendline) yang dihasilkan dari hasil uji kuat tekan di Gambar 2, menunjukan nilai kuat tekan optimum didapatkan pada rasio L/D 75 yang dinyatakan dengan Pers. 6. Kenaikan rasio serat 10, akan menurunkan kuat tekan sebesar 2,7163 MPa. Nilai kuat tekan optimum sesuai Pers. 6 didapatkan untuk serat dengan rasio L/D 75 sebesar 20,19 MPa atau 19,47\% lebih besar dari rencana $(16,9 \mathrm{MPa})$ dan $16,60 \%$ dari beton tanpa serat atau beton referensi (17,316 MPa). Modulus elastisitas beton dengan menggunakan Persamaan, $E_{c}=4700 \sqrt{f_{c}^{;}}$(SNI 2847:2019) untuk beton dengan serat kawat baja 1\% berat volume, untuk rasio L/D 75 memberikan nilai $21.118 \mathrm{MPa}$.

$$
f_{c}^{\prime}=-5 \cdot 10^{-3}\left(\frac{L}{D}\right)^{2}+0,6969\left(\frac{L}{D}\right)-3,9527
$$

dengan:

$f_{c}^{\prime} \quad=$ kuat tekan rencana umur 28 hari $(\mathrm{MPa})$,

$L \quad=$ panjang serat baja dalam campuran beton $(\mathrm{mm})$,

$D \quad=$ diameter serat baja dalam campuran.

\subsubsection{Pengaruh rasio $\mathrm{L} / \mathrm{D}$ pada kuat tarik belah beton serat $1 \%$ dari berat volume}

Kekuatan tarik belah beton rata-rata, $f_{c S}$ yang didapatkan sesuai Tabel 4 untuk beton referensi sebesar 2,317 MPa dan beton dengan variasi rasio L/D antara 2,387-2,582 MPa. Menggunakan Pers. 5, untuk kuat beton 16,9 MPa, didapatkan nilai kuat tarik belah rencana, $f_{c S}=2,251 \mathrm{MPa}$. Kuat tarik belah beton referensi lebih besar 2,9\% dari rencana, sedangkan kuat tarik belah beton dengan variasi rasio L/D memberikan kuat tarik belah terbesar pada rasio L/D 75 naik sebesar $14,7 \%$ dari rencana atau lebih $11,44 \%$ dari beton referensi.

Persamaan (trendline) yang dihasilkan dari hasil uji kuat tarik belah di Gambar 3, menunjukan nilai kuat tarik belah optimum didapatkan pada rasio L/D 75 yang dinyatakan dengan Pers. 7. Kenaikan rasio serat 10, akan menurunkan kuat tarik belah sebesar 1,232 $\mathrm{MPa}$. Nilai kuat tarik belah optimum sesuai Pers. 7 didapatkan untuk serat dengan rasio 75 sebesar 2,753 $\mathrm{MPa}$, atau 22,29\% lebih besar dari rencana $(2,251 \mathrm{MPa})$ dan $18,83 \%$ dari beton tanpa serat atau beton referensi $(2,317$ $\mathrm{MPa})$.

$$
f_{c S}=-3 \cdot 10^{-4}\left(\frac{L}{D}\right)^{2}+0,0489\left(\frac{L}{D}\right)+0,7728
$$

dengan:

$f_{c S}=$ kuat tarik belah umur 28 hari (MPa),

$L \quad$ = panjang serat baja dalam campuran beton $(\mathrm{mm})$,

$D \quad=$ diameter serat baja dalam campuran.

Semakin besar rasio L/D maka kuat tarik belah beton serat menggunakan kawat bendrat akan semakin turun, jika merujuk Pers. 7, sampai dengan rasio 95 atau panjang serat sekitar $\pm 75 \mathrm{~mm}$, kuat tarik belah sebesar 2,711 MPa masih meningkat, lebih dari rasio L/D 95, kuat tarik belah menurun, karena kandungan serat dalam campuran beton segar sulit dicampur. Hal ini sejalan dengan hasil penelitian sebelumnya bahwa serat lebih dari $60 \mathrm{~mm}$ (rasio L/D \pm 60 ) akan menurunkan kuat tekan (Ariatama, 2007; Juwarnoko, 2019; Sentani, 2007; Sugiarto, 2017).

\subsubsection{Pengaruh rasio $\mathrm{L} / \mathrm{D}$ pada kuat lentur beton serat $1 \%$ dari berat volume}

Kekuatan lentur beton rata-rata, $f_{c f}$ didapatkan sesuai Tabel 5 untuk beton referensi sebesar 3,144 MPa dan beton dengan variasi rasio L/D antara 2,52-4,070 MPa. Menggunakan Pers. 1, untuk kuat beton $16,9 \mathrm{MPa}$, didapatkan nilai kuat lentur rencana, $f_{c f}=3,083 \mathrm{MPa}$. Kuat lentur rata-rata 
beton referensi lebih besar 1,97\% dari rencana, sedangkan kuat lentur beton dengan variasi rasio L/D memberikan kuat lentur terbesar pada rasio L/D 75 naik sebesar 12,06\% dari rencana atau lebih 9,89\% dari beton referensi. Nilai kuat lentur maksimum dari Tabel 5 didapatkan sebesar 3,455 MPa untuk rasio L/D 62,5 dan nilai minimum sebesar 2,520 MPa. Kecenderungan nilai kuat lentur sesuai Tabel 5, dinyatakan dengan Pers. 8, didapatkan untuk penambahan rasio serat $\mathrm{L} / \mathrm{D}=10$, kuat lentur akan bertambah sebesar 1,9949 MPa sampai dengan rasio L/D 75 kuat lentur sebesar 3,288 MPa. Kenaikan rasio L/D lebih dari 75 menurunkan kuat lentur beton serat. Menggunakan Pers. 8, rasio L/D 75 memberikan nilai kuat lentur beton serat sebesar 3,638 MPa, yang nilainya $18,01 \%$ lebih besar dari rencana $(3,083 \mathrm{MPa})$ dan $1,97 \%$ dari beton tanpa serat atau beton referensi $(3,144 \mathrm{MPa})$.

dengan:

$$
f_{c f}=-4 \cdot 10^{-4}\left(\frac{L}{D}\right)^{2}+0,0623\left(\frac{L}{D}\right)+1,2156
$$

$f_{c f}=$ kuat lentur umur 28 hari $(\mathrm{MPa})$,

$L \quad=$ panjang serat baja dalam campuran beton $(\mathrm{mm})$,

$D \quad=$ diameter serat baja dalam campuran .

\subsection{Diskusi}

Hasil penelitian menunjukan penambahan rasio L/D menyebabkan nilai slump menurun 20-35 mm yang sesuai dengan (ACI 544.5R, 2010), yang menyatakan penambahan volume serat akan menurunkan nilai slump dibandingkan dengan campuran non-serat dalam kisaran 25 hingga 102 $\mathrm{mm}$. Berat isi beton tanpa serat atau beton referensi tidak berbeda, karena penambahan volume serat dalam campuran beton relatif kecil dibandingkan berat volume campuran, dapat dinyatakan bahwa rasio L/D tidak berpengaruh terhadap berat isi beton.

Kuat tekan, kuat tarik belah dan lentur beton serat dengan $1 \%$ berat volume dalam campuran menunjukan rasio L/D untuk beton serat baja (kawat bendrat) sampai dengan 62,5-75,0 masih dapat memberikan nilai optimum. Peningkatan volume serat, meningkatkan secara linear kekuatan tarik dan kekuatan komposit beton yang sesuai dengan ACI 5445R (2010).

Rasio L/D sebesar 62,5-75,0 untuk kawat bendrat dengan diameter $0,8 \mathrm{~mm}$, didapatkan panjang 50-60 mm, hal ini sesuai dengan penelitian sebelumnya (Juwarnoko, 2019; Sugiarto, 2017), bahwa panjang $60 \mathrm{~mm}$ dengan proporsi serat 1,5\% meningkatkan kuat tekan sampai 40,14\% kuat tekan (Sentani, 2007). Rasio yang lebih besar akan menurunkan kuat tekan (Ariatama, 2007; Juwarnoko, 2019; Sentani, 2007; Sugiarto, 2017). Rasio tipikal berkisar 30-150 dari sekitar 30 masih dapat meningkatkan kuat tekan, kuat tarik belah dan lentur beton (Wafa, 1990), rekomendasi (ACI $544.5 \mathrm{R}, 2010$ ) rasio L/D sebesar 30-150 atau panjang berkisar dari 6,4 hingga $76 \mathrm{~mm}$. Sesuai dengan hasil yang didapatkan rasio L/D antara 62,5-75,0 menghasilkan kuat tekan, kuat tarik belah dan lentur beton serat dengan $1 \%$ berat volume dalam campuran yang masksimum.

\section{Kesimpulan}

Menjawab pertanyaan penelitian pertama "Seberapa besar signifikasi perbedaan beton mutu 16,9 MPa menggunakan serat kawat baja (bendrat) proporsi $1 \%$ dalam campuran dengan variasi panjang (rasio L/D)?", pada taraf nyata, $\alpha=0,05$ dengan uji-T menunjukan bahwa ada perbedaan karakteristik antara beton yang menggunakan serat kawat baja (bendrat) dengan proporsi $1 \%$ berat volume campuran dan variasi rasio L/D. Jawaban atas pertanyaan "Bagaimana karakteristik kuat tekan, kuat tarik belah beton mutu 16,9 MPa menggunakan serat kawat baja (bendrat) dengan proporsi $1 \%$ dalam campuran dengan variasi panjang (rasio L/D)?", dapat dinyatakan (1) Bahan penyusun beton yang digunakan dalam pencampuran bahan memenuhi SNI terutama untuk sifat dan karakteristik agregat memenhui syarat gradasi sesuai (ACI 544.5R, 2010); (2) berat isi tidak 
ada perbedaan yang signifikan antara beton referensi yang menggunakan variasi rasio L/D; (3) Nilai slum yang dihasilkan beton referensi $95 \mathrm{~mm}$ lebih rendah dari rencana $120 \pm 20 \mathrm{~mm}$ atau 20 $35 \mathrm{~mm}$ penurunan slum beton serat dengan variasi rasio L/D terhadapi beton referensi; (4) Pengunaan serat kawat baja (bendrat) $1 \%$ dalam volume campuran dengan variasi rasio L/D meningkatkan kekuatan tekan, kekuatan tarik belah dan kekuatan lentur; (5) rasio L/D optimum antara 62,5-75 untuk rasio L/D 75 memberikan (a) kuat tekan 20,19 MPa atau 19,47\% lebih besar dari rencana (16,9 MPa) dan $16,60 \%$ dari beton tanpa serat atau beton referensi $(17,316 \mathrm{MPa})$; (b) Kuat tarik belah 2,753 MPa, atau 22,29\% lebih besar dari rencana (2,251 MPa) dan 18,83\% dari beton tanpa serat atau beton referensi $(2,317 \mathrm{MPa})$; dan kuat lentur 3,292 $\mathrm{MPa}$, yang nilainya $6,66 \%$ lebih besar dari rencana $(3,083 \mathrm{MPa})$ dan $4,60 \%$ dari beton tanpa serat atau beton referensi $(3,144 \mathrm{MPa})$.

\section{Ucapan Terima Kasih}

Penelitian dapat dilaksanakan dengan dibiayai oleh Dana BLU POK Fakultas Teknik Universitas Negeri Jakarta, Berdasarkan Surat Keputusan Penjabat Pembuat Komitmen Fakultas Teknik, Universitas Negeri Jakarta No. 291/UN39/PT.01.02/2021, Tanggal: 15 April 2021, dan Surat Perjanjian Penugasan Dekan Fakultas Teknik Nomor: 068a/5.FT/PP/IV/2021, Tanggal: 26 April 2021, Tahun Anggaran 2021.

\section{Daftar Pustaka}

American Concrete Institute, 2002, Report on Fiber Reinforced Concrete, (ACI 544.1R-96 (Reapproved 2002)) Farmington Hills, MI.

American Concrete Institute, 2010, Report on the Physical Properties and Durability of FiberReinforced Concrete, American Concrete Institute (ACI 544.5R 2010), ACI Committe, Farmington Hill, MI.

Ariatama, A., 2007 Pengaruh Pemakaian Serat Kawat Berkait pada Kekuatan Beton Mutu Tinggi Berdasarkan Optimasi Diameter Serat, (Tesis), Program Magister Teknik Sipil Program Pascasarjana, Universitas Diponogoro, Semarang

ASTM International, 2013 Standard Test Method for Surface Moisture in Fine Aggregate, ( ASTM C70-13),West Conshohocken, PA.

ASTM International, 2015, Standard Test Method for Relative Density (Specific Gravity) and Absorption of Fine Aggregate (ASTM C127-15 and ASTM C128 - 15), West Conshohocken, PA

ASTM International, 2016 Organic Impurities in Fine Aggregates for Concrete, Reproduction (ASTM C40 / C40M - 16 (2016), West Conshohocken, PA.

ASTM International, 2017 Standard Test Method for Clay Lumps and Friable Particles in Aggregates (ASTM C142 / C142M - 17), West Conshohocken, PA.

ASTM International, 2017, Standard Test Method for Bulk Density ("Unit Weight") and Voids in Aggregate. (ASTM C29 / C29M - 17a) West Conshohocken, PA.

ASTM International, 2021 Standard Test Method for Flexural Strength of Concrete (Using Simple Beam with Third-Point Loading). ASTM C78/C78M-21 West Conshohocken, PA. https://doi.org/10.1520/C0078_C0078M-21

Badan Standardisasi Nasional, 1997, Metode Pengujian Agregat Halus atau Pasir Yang Mengandung Bahan Plastik Dengan Cara Setara Pasir (SNI 03-4428-1997 ) BSN, Jakarta. 
Badan Standardisasi Nasional, 1998 Metode Pengujian Bobot Isi dan Rongga Udara dalam Agregat (SNI 03-4804-1998), BSN, Jakarta.

Badan Standardisasi Nasional, 2012 Metode Uji untuk Analisis Saringan Agregat Halus dan Agregat Kasar (SNI ASTM C136:2012), BSN, Jakarta.

Badan Standardisasi Nasional, 2014 Metode Uji Bahan Organik dalam Agregat Halus untuk Beton (SNI 2816:2014), BSN, Jakarta.

Badan Standardisasi Nasional, 2014 Metode Uji Kekuatan Tarik Belah Spesimen Beton Silinder (SNI 2491:2014), Badan BSN, Jakarta.

Badan Standardisasi Nasional, 2016 Metode Uji Berat Jenis dan Penyerapan Air Agregat Halus (SNI 1970:2016). BSN, Jakarta.

Badan Standardisasi Nasional, 2016 Metode Uji Kadar Air Permukaan Agregat Halus (SNI 8319:2016), BSN, Jakarta.

Badan Standardisasi Nasional, 2019 Persyaratan Beton Struktural untuk Bangunan Gedung dan Penjelasan (ACI 318M-14 dan ACI 318RM-14, MOD) (SNI 2847:2019), BSN, Jakarta.

Departemen Pemukiman dan Prasarana Wilayah, 2003 Pedoman Perencanaan Perkerasan Jalan Beton Semen (Pd T-14-2003) Departemen Pemukiman dan Prasarana Wilayah, Jakarta

Foermansah, R., 2013 Tinjauan Kuat Tekan Dan Kuat Tarik Belah Beton Dengan Serat Kawat Bendrat Berbentuk “W” Sebagai Bahan Tambah:(Skripsi S1 Issue Naskah publikasi), Program Studi Teknik Sipil, Fakultas Teknik, Universitas Muhammadiyah Surakarta

Hafiz S.G, A., Rommel, E., \& Prasetyo, L., 2015. Pengaruh Pemberian Jumlah Dan Rasio (L/D) Serat Bendrat Terhadap Sifat Mekanik Beton. Jurnal Media Teknik Sipil, 13(1), 13. https://doi.org/10.22219/jmts.v13i1.2538

Junus, N., 2017 Efek Penambahan Serat Kawat Bendrat terhadap Kuat Tekan dan Kuat Tarik Beton yang Dirawat melalui Metode Wet and Dry Curing. Jurnal Penelitian Enjiniring, 21(1), 41-47. https://doi.org/10.25042/jpe.052017.06

Juwarnoko, 2019 Pengaruh Penambahan Serat Kawat Bendrat pada Campuran Beton Terhadap Kuat Tekan Dan Kuat Tarik Beton (Skripsi), Pendidikan Teknik Bangunan Jurusan Teknik Sipil Fakultas Teknik Universitas Negeri Semarang, Semarang

Kawulusan, J. A., Manalip, H., \& Dapas, S. O., 2019 Pemeriksaan Kuat Tarik Belah Beton Serat Kawat Bendrat dengan Variasi Sudut Tekuk pada Kedua Ujungnya. Jurnal Sipil Statik, 7(5), $513-526$.

Kurniawan, D. 2021 Analisis Beton Serat dengan Kawat Bendrat dan Substitusi Agregat Kasar dengan Limbah Plastik. Ensiklopedia of Journal, 3(2), 1-9.

Malino, L., Wallah, S. E., \& Handono, B. D., 2019 Pemeriksaan Kuat Tekan Dan Kuat Tarik Lentur Beton Serat Kawat Bendrat yang Ditekuk dengan Variasi Sudut Berbeda. Jurnal Sipil Statik, 7(6), 711-722.

Mulyono, T., 2003 Teknologi Beton. Andi Offset, Yogyakarta

Mulyono, T., 2015 Teknologi Beton: dari Teori ke Praktek(G. Bachtiar (ed.)). LPP Press.

Mulyono, T., 2021. Bahan Bangunan dan Konstruksi. Stiletto Indie Book, Yogyakarta

Nugraha, I. D., 2018 Studi Karakteristik Beton Serat Kawat Bendrat (Skripsi S1), Departemen Teknik Sipil Fakultas Teknik Universitas Hasanuddin, Makasar

Peraturan Menteri Pekerjaan Umum dan Perumahan Rakyat Republik Indonesia Nomor 28/PRT/M/2016 Tentang Pedoman Analisis Harga Satuan Pekerjaan Bidang Pekerjaan Umum, JDIH Kementerian PUPR, Jakarta 
Prayitno, S., Supardi, \& Asmara, D. A. Y, 2016 Pengaruh Penambahan Serat Kawat Ikat (Bendrat) Pada Kuat Tekan Dan Lentur Beton Bertulang dengan Abu Sekam Padi dan Accelerator. EJurnal MATRIKS TEKNIK SIPIL, September, 899-908.

Sentani, A. 2007 Pengaruh Variasi Panjang Serat Kawat Bendrat Terhadap Kuat Tekan, Kuat Tarik, Dan Kuat Lentur Beton Pasir (Dengan Berat Serat 1,5\% dari Berat Beton), (Skripsi S1), Jurusan Teknik Sipil Fakultas Teknik Sipil Dan Perencanaan Universitas Islam Indonesia, Yogyakarta

Sugiarto, D., 2017 Pengaruh Penambahan Serat Kawat Bendrat Terhadap Kuat Tekan Beton (Skripsi S1), Jurusan Teknik Sipil Fakultas Teknik Sipil Universitas Semarang, Semarang.

Uluhiyah, A., 2018 Pengaruh Penambahan Serat Bendrat dan Penambahan Serbuk Kaca sebagai Pengganti Sebagian Agregat Halus Terhadap Sifat Mekanik Beton (Skripsi S1), Jurusan Teknik Sipil Fakultas Teknik Universitas Mataram, Mataram

Wafa, F. F., 1990. Properties and Applications of Fiber Reinforced Concrete. JKAU: Eng. Sci, 2, 49-63. 